\title{
FROM GARRINCHA'S LEGS TO NEYMAR'S LEGS: THE GENU VARUM AND VALGUM IN SOCCER. HISTORICAL OVERVIEW AND UPDATE
}

\author{
DAS PERNAS DE GARRINCHA ÀS DE NEYMAR: \\ OS GENU VARUM E VALGUM NO FUTEBOL. \\ PANORAMA HISTÓRICO E ATUALIZAÇÃO
}

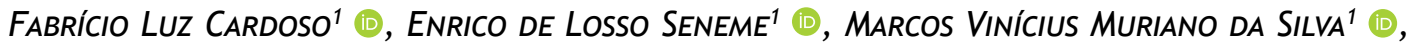 \\ Marcos HeNRIQUe Ferreira LARAYA ${ }^{1}$ (1), José ANTONIO GalbiatTII ${ }^{2}$ (1), RICARDo HIDEKI YANASSE ${ }^{1}$ (1)
}

1. Hospital das Clínicas da Faculdade de Medicina de Marília, Serviço de Ortopedia e Traumatologia, Marília, SP, Brazil.

2. Faculdade de Medicina de Marília, Disciplina de Anatomia Humana, Marília, SP, Brazil.

\section{ABSTRACT}

The presence of abnormalities in knee alignment (genu varum and genu valgum) is extremely common in soccer. It can occur in the junior league / youth academy and perpetuate itself throughout the professional career. The consequences of years of high-level sports practice in players with genu varum / genu valgum can be harmful to the knees. By observing football matches of the present and the past, the authors of the article noted that great Brazilian soccer players were, or are, affected by the malalignment of the knees: Garrincha (the most famous), Leandro, Dunga, Romário, Rivaldo and Neymar. This study aims to discuss the relationship between high-performance sport and the development of these orthopedic deformities, serving as a tool for updating the trauma-orthopedic knee subspecialty. Level of Evidence III, Retrospective comparative study.

Keywords: Soccer. Genu Varum. Genu Valgum. Bow Legs. Knock Knee.

\section{RESUMO}

A presença de anormalidades no alinhamento dos joelhos (geno varo e geno valgo) é extremamente comum no futebol. Seu aparecimento pode ocorrer quando os jogadores estão nas categorias de base e se perpetuar durante a carreira profissional. As consequências de anos de prática esportiva em alto nível em jogadores com geno varo/geno valgo podem ser deletérias aos joelhos. A partir da observação de jogos de futebol do presente e do passado, os autores do artigo notaram que grandes nomes brasileiros deste esporte foram ou são acometidos pelo desalinhamento dos joelhos: Garrincha - o mais famoso -, Leandro, Dunga, Romário, Rivaldo e Neymar. O presente estudo tem como objetivo discutir a relação entre o esporte de alto rendimento e o desenvolvimento dessas deformidades ortopédicas, servindo como ferramenta de atualização da subespecialidade traumato-ortopédica do joelho. Nível III de Evidência, Estudo Retrospectivo Comparativo.

Descritores: Futebol. Geno Varo. Geno Valgo. Joelhos Arqueados. Perna em Tesoura.

Citation: Cardoso FL, Seneme EL, Silva MVM, Laraya MHF, Galbiatti JA, Yanasse RH. From Garrincha's legs to Neymar's legs: the genu varum and valgum in soccer: historical overview and update. Acta Ortop Bras. [online]. 2021;29(5):277-282. Available from URL: http://www.scielo.br/aob.

\section{INTRODUCTION}

Soccer is the most played sport in the world. Data from FIFA, the world's highest soccer entity, show a total estimate of 270 million players around the world in the year 2006. ${ }^{1}$ However, this number can be considered to be even higher if we take in account that the last "FIFA Big Count" estimate was done 13 years ago - therefore it is outdated - and that the number of female players has grown and the sport has grown in popularity in recent years.

It is curious to observe that soccer players develop a sort of bowing of their legs, which is commonly nicknamed "pliers legs" or "cowboy legs". It is the so-called genu varum. In addition to this angular deformity, another axial deviation that can be found is called genu valgum, commonly called "knock knee", where the knees approach each other leaving the legs shaped like an " $X$ ". Based on empirical knowledge about the frequent observation of the two aforementioned conditions in soccer players of different nationalities, the objective of this article is to provide a historical account of the manifestation of deformities in well-known soccer players and to update the subject, making this study a tool for updating the knee orthopedic trauma subspecialty.

All authors declare no potential conflict of interest related to this article.

The study was conducted at Faculdade de Medicina de Marília.

Correspondence: Fabrício Luz Cardoso. Av. Monte Carmelo, 800, Fragata, Marília, SP, Brazil, 17519030. fabricioramalhense@gmail.com 


\section{MATERIALS AND METHODS}

We searched the literature using the MeSH descriptors "Soccer," "Genu varum" and "Genu Valgum" in the following databases: PubMed, EMBASE, Lilacs, Scopus, Web of Science, SciELO and BVS. Few papers on the subject were found. In addition to the articles, we searched for information about players with genu varum or valgum in printed newspapers, audiovisual material, sports websites and historical books. Finally, we resorted to renowned textbooks of anatomy, semiology, orthopedics, sports traumatology and sports medicine, and online material from the UpToDate platform as a basis for the update.

The study was conducted in accordance with the Helsinki Declaration of the World Medical Association on ethical principles for medical research involving human beings, and does not require analysis by the Ethics Committee for Institutional Human Research (CEP).

\section{Anatomy and biomechanics of the knee}

The knee joint has three articulations: two articulations between the femur and the tibia (one lateral and one medial) and one articulation between the femur and the patella. Its stability depends on adjacent muscles and their tendons, and the ligaments between the femur and the tibia. The muscles are the main factor of stability. ${ }^{2}$ The knee has an articular capsule made up of an outer fibrous layer and an inner synovial membrane. The femur is located above the fibrous layer, the condyles and the intercondylar fossa are on the posterior side, the tibia is on the lower side and in the anterior portion are the tendon of the quadriceps femoris, the patella and the patellar ligament. ${ }^{2}$ The joint capsule is strengthened by five ligaments: 1) Patellar ligament; 2) Fibular collateral ligament (lateral collateral ligament); 3) Tibial collateral ligament (medial collateral ligament); 4) Oblique popliteal ligament; 5) Arcuate popliteal ligament. ${ }^{2}$

The knee also has intra-articular ligaments. The anterior cruciate ligament (ACL) prevents the posterior detachment of the femur over the tibia and the hyperextension of the joint. The posterior cruciate ligament (PCL) prevents the anterior dislocation of the femur over the tibia or the posterior dislocation of the tibia over the femur and helps prevent hyperflexion of the knee. ${ }^{2}$

There are also two structures in the knee joint that function as "shock absorbers", namely the medial and lateral menisci. They are structures composed of fibrocartilage and absorb mechanical impacts. ${ }^{2}$

There are also the coronary ligaments (they are parts of the joint capsule) and the transverse ligament of the knee that joins the anterior margins of the menisci and fixes them during knee movements. ${ }^{2}$ The most important movements that the knee performs are extension and flexion, although slight rotation also occurs when the knee is flexed. Healthy knees can extend up to $0^{\circ}$. The main muscle involved in this extension process is the quadriceps femoris, and it is most efficient when the hip joint is extended. ${ }^{2}$

The degree of knee flexion depends on the situation of the hip. With the hip extended, the knee reaches $120^{\circ}$ of flexion. With the hip flexed, the knee reaches $140^{\circ}$. In addition, the knee can be passively flexed by $160^{\circ}{ }^{2}$

The knee can also perform a medial rotation up to $10^{\circ}$ when flexed and $5^{\circ}$ when extended. Lateral rotation can reach $30^{\circ}$ when the knee is flexed. ${ }^{2}$

\section{Axial deviations of the lower limbs}

\section{Etiology and epidemiology}

Bow legs and "X-shaped" knees are among the most common musculoskeletal anatomical variations found in health services delivering primary pediatrics care, and they are a common reason for referral to the subspecialty of pediatric orthopedics. ${ }^{3}$

The alignment of the lower extremities undergoes a predictable progression from varum (bow legs), to neutral, to valgum (X-shaped knees) and back to neutral in the first seven years of life..$^{3,4}$ The final alignment of adult lower limbs is slightly valgum. . $^{3,4}$

Physiological genu varum is found between ages 0 and 2; on the other hand, pathological genu varum (Blount's disease, also called tibia vara) has two manifestation periods: 1) in children up to 3 years old due to obesity or early walking; 2 ) in adolescents, with insidious onset in individuals aged 8 or older. ${ }^{5}$ Other causes include: nutritional rickets and other metabolic bone diseases, skeletal dysplasia, infection, trauma and neoplasms. ${ }^{3}$

Physiological genu valgum occurs between ages 2 and 5 and can be considered pathological when it exceeds the age limit. It is usually caused by bone tumors, but may also have a metabolic cause by renal oestodystrophy or other causes such as trauma (for example, Cozen fracture), mucopolysaccharidosis and infection. ${ }^{5}$

In adulthood, the physiological tibiofemoral angle is 5-7 degrees. ${ }^{6-8}$

\section{Pathophysiology}

The law of Hueter-Volkman ${ }^{9,10}$, a century and a half ago, postulated that increased pressure parallel to the axis of the epiphysis inhibits growth, while decreased in pressure stimulates growth. In addition, these changes of compressive forces cause asymmetric growth of the joint. Frost's, "Chondral Modeling"11 theory suggests that physiological load stimulates growth, while larger or smaller loads inhibit growth.

The femur assumes a diagonal position in the thigh, while the position of the tibia in the leg is almost vertical, creating an angle in the knee between the longitudinal axes of these bones clinically called the $Q$ angle. ${ }^{2}$ This angle is assessed by drawing a line that goes from the anterior superior iliac spine to the middle of the patella and a second vertical line that runs through the middle of the patella and the tibial tubercle. ${ }^{2}$ In its normal anatomy, the angle of the femur in the thigh places the middle of the knee joint directly below the head of the femur in standing position, centralizing the line of weight support in the intercondylar region of the knee. ${ }^{2}$

The medial angulation of the leg relative to the thigh, in which the femur is abnormally vertical and the $Q$ angle is small, causes the emergence of genu varum. Genu valgum occurs due to the lateral angulation of the leg relative to the thigh with a large $Q$ angle $\left(>17^{\circ}\right){ }^{2}$

\section{Complications arising from genu varum and genu valgum}

Because in genu varum the weight support line is located medially to the center of the knee, there is excess pressure on the medial face of the knee joint, resulting in arthrosis and also exaggerated tension of the fibular collateral ligament. ${ }^{2}$ Genu varum may also be associated with cavus foot, internal rotation of the tibia, excessive abduction of the hip or external rotation of the hip. ${ }^{12}$

As a result of the excessive angle of the knee in genu valgum, the weight support line is located laterally to the center of the knee, which causes hyperextension of the tibial collateral ligament and excessive tension on the lateral meniscus and cartilages of the lateral condyles of the femur and the tibia. ${ }^{2}$ The patella, commonly pulled laterally by the tendon of the vastus lateralis muscle, is pulled even more intensely to the side when the leg is extended in genu valgum, which makes its joint with the femur abnormal. ${ }^{2}$ Genu valgum can be associated with flat foot. ${ }^{12}$

\section{Physical examination of the knee for a clinical diagnosis of angular deformities}

Didactically, the orthopedic examination of the knee is divided into three stages: inspection (static and dynamic), palpation and specific tests. The most important data for the diagnosis of axial 
deviations of the knee comes from the inspection, for which reason this step will be the analyzed in more detailed below.

\section{Inspection (standing patient)}

Alignment from head to feet must be observed. The plumb line test can detect abnormalities such as dorsal kyphosis, hyperlordosis, hip flexion or extension or knee recurvatum. ${ }^{13}$

In frontal inspection, it is possible to observe and assess lower limb alignment on the same plane (varum and valgum) or on two (torsional deviations), patellar alignment, $\mathrm{Q}$ angle, presence of edema, stroke, bruising, muscle atrophies, dynamic changes in the various phases of gait and presence of deformities. ${ }^{13}$

The emergence of latero-lateral deformity (thrust or buckling) during the support phase of gait may indicate degenerative arthritis with cartilage erosion and varum deviation of the knee, or peripheral ligament failure associated with anterior cruciate ligament $(A C L)$ injury. Recurvatum and limitations to knee extension are revealed at this stage of the examination and can indicate joint blockage or even position resulting from hip flexion deformity. ${ }^{13}$

During static inspection and gait examination, indirect changes are detected that may be related to joint disease, such as abnormal positions of the contracted hip (abduction or adduction). ${ }^{13}$

Gait examination detects lameness, and studying the support time while walking allows the distinction of lameness caused by knee dysfunction or hip dysfunction. Trendelenburg's sign (found in people with weak abductor musculature of the hip) is recognized at this moment of the examination. ${ }^{13}$

The arrangement of the feet and the footprint while walking can change in torsional deformities, especially of the tibia. Patellar alignment should be investigated through the $Q$ angle ${ }^{13}$ (normal value between 10 and 15 degrees in men and 15 to 20 degrees in women. When the knee is flexed at 90 degrees, its value corresponds to zero degree). ${ }^{14}$ Joint mobility and muscle contours are also evaluated; when different from one side and the other, they can characterize atrophy. ${ }^{13}$

\section{Inspection (sitting patient)}

Patellar height is observed. When it is high, it forms an angulation with the patellar ligament, dissociating the quadriceps lever into three arms: the quadriceps muscle of the thigh, the patella and the patellar tendon. Patellar tendon alignment and its insertion in the TAT is also checked. The bayonet sign on the patella or knee occurs due to an increase in the $Q$ angle caused by a torsional deformity with lateral deviation of the TAT.13

With the knee extended, the presence of a patellar dislocation at the end of the movement may indicate patellofemoral instability. ${ }^{13}$ If the patient is lying and their knee is flexed at $30^{\circ}$, the bayonet sign on the patella can be detected more easily. The $Q$ angle can also be measured more accurately in this position because the patella is placed entirely in the intercondylar notch. ${ }^{13}$

Flexion and extension of the knee allow assessing the presence of crepitus (initial, terminal and upper) and possible joint pops. ${ }^{13}$

\section{Inspection (patient lying down)}

Four movements are assessed: flexion, extension, internal rotation of the tibia and external rotation of the tibia. Physiological flexion and extension range from $0^{\circ}$ to $135^{\circ}$ of movement and physiological rotation of the tibia ranges from $0^{\circ}$ to $15^{\circ} .^{13}$

\section{Palpation (patient sitting or lying down)}

With the patient in a position that facilitates examination, palpation should be performed in the following sequence: 1) bone structures (upper, middle and lower poles of the patella; tibial tubercles; Gerdy's tubercle; head of the fibula and medial and lateral epicondyls); 2) soft tissues (pre-and infra patellar bursae; joint line; popliteal fossa and tendon insertions). ${ }^{13}$

\section{Specific tests (according to semiotechnics)}

The examination proceeds to either special tests, if there is a suspicion of other conditions associated with angular deformities, or to differential diagnosis. The tests are subdivided into: a) menisci tests (McMurray; Appley; Steinmann; Smillie and Trendelenburg gait) and; b) ligament function tests (Lachman or Richey; anterior drawer; posterior drawer; posterolateral drawer; Jerk or rebound; pivot-shift or Mclntoch; reverse pivot-shift or Jakob's test; RRE - external rotation recurvatum; hyperextension or recurvatum; passive posteriorization of the tibia at $90^{\circ}$ or Godfrey; abduction stress or valgum and adduction stress or varum). ${ }^{13}$

\section{Radiographic diagnosis}

In a panoramic radiography of the lower limbs, we can observe some anatomical parameters that allow us to distinguish physiological deviations from pathological ones: 1) XR Varum: metadiaphyseal angle of the tibia (MDAT): $<9^{\circ}$ is normal, $>16^{\circ}$ is pathological/ Blount; 2) XR Valgum: alignment in X-ray: in normal adults, valgum is 6 degrees. $^{5}$

\section{Historical context in Brazilian soccer}

When we think of players with deformities in lower limb alignment, the picture of the great Brazilian right-hander Mané Garrincha comes to mind (Figures 1 and 2). He was nicknamed "Crooked leg Angel" on account of his noticeable bow legs. According to Ruy Castro's accounts ${ }^{15}$ and other newspaper sources, ${ }^{16-19}$ Garrincha was born with bone deformities and was subsequently affected by poliomyelitis in his childhood, the sequelae of which aggravated the axial deviations of his lower limbs. His right leg was $6 \mathrm{~cm}$ shorter than the left, causing a medial deviation (genu valgum) towards the left leg. His left leg also had a similar shape, with a lateral deviation (genu varum) ${ }^{17,19}$ As a result of that malalignment, Garrincha probably had a dislocated hip and suffered from scoliosis.

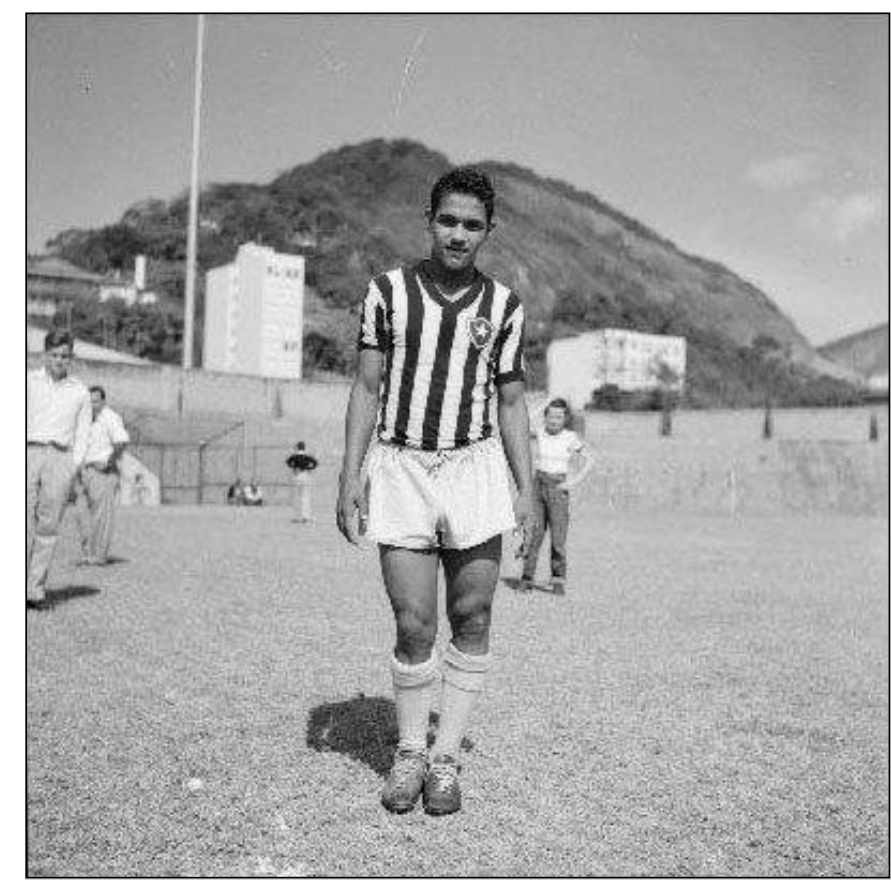

Figure 1. Mané Garrincha in Botafogo.

Source: Official Twitter page of Botafogo Futebol e Regatas. ${ }^{20}$ 


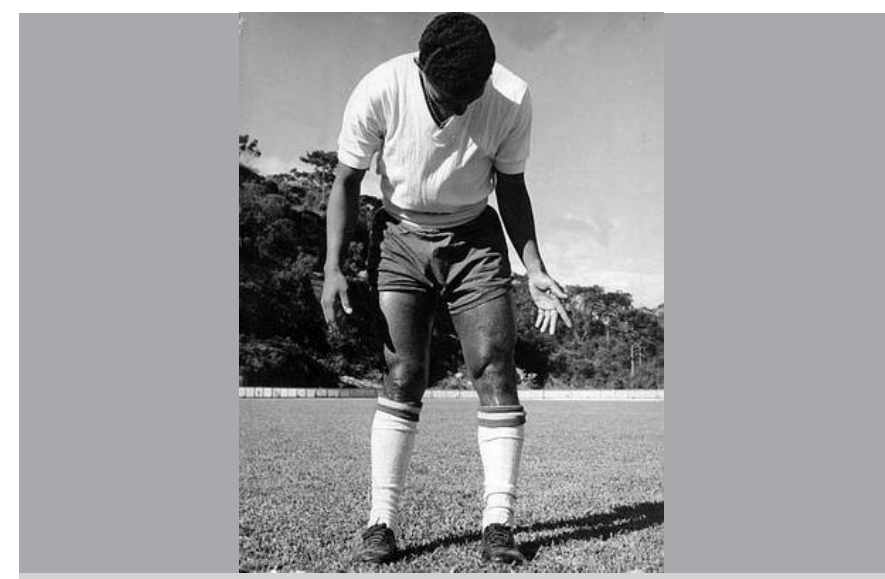

Figura 2. Mané Garrincha looking at his legs Source: Agência Estadão. ${ }^{21}$

Another skilled Brazilian player who also has lower limb malalignment is right-back Leandro, who played remarkable seasons for Flamengo and played the 1982 World Cup whit what is regarded as one of the best teams of all time. ${ }^{22,23}$ The right back who impressed the world in the squad led by coach Telê Santana had a case of genu varum. ${ }^{22,23}$ Although his deviation is not as evident as Garrincha's, Leandro even underwent a surgical procedure in an attempt to align his lower limbs, without success. ${ }^{23}$

Following the history of great players in the Brazilian national team, we find that forward Romário, one of the main players in the squad that won the fourth World Cup, also had genu varum on his left knee.18,24 Nicknamed "Baixinho" ("Shortie"), he underwent valgus tibial osteotomy associated with an arthroscopy and as a result became $2 \mathrm{~cm}$ taller. ${ }^{25,26}$ Captain of the 1994 world champion squad and former coach of the Brazilian soccer team, Dunga, who played as a midfielder, was also affected by genu varum in his left knee. He underwent the same surgical procedures as Romario to align of the axis of his knee and correct meniscal lesions. ${ }^{27,28}$

In the squad that won the fifth world championship, midfielder Rivaldo, ${ }^{29}$ who played an important part, had genu varum mainly in his right knee. ${ }^{30} \mathrm{He}$ underwent knee surgery to correct the deformity at age 43 and retired from the sport afterwards. ${ }^{30}$

Although there are not many direct reports on the subject in press sources, ${ }^{31}$ one can notice in his performances in matches and training that Neymar Júnior, left-hander of the Brazilian team and one of the main players of world soccer, has a certain degree of bow leg, more noticeable in his left knee (Figure 3).

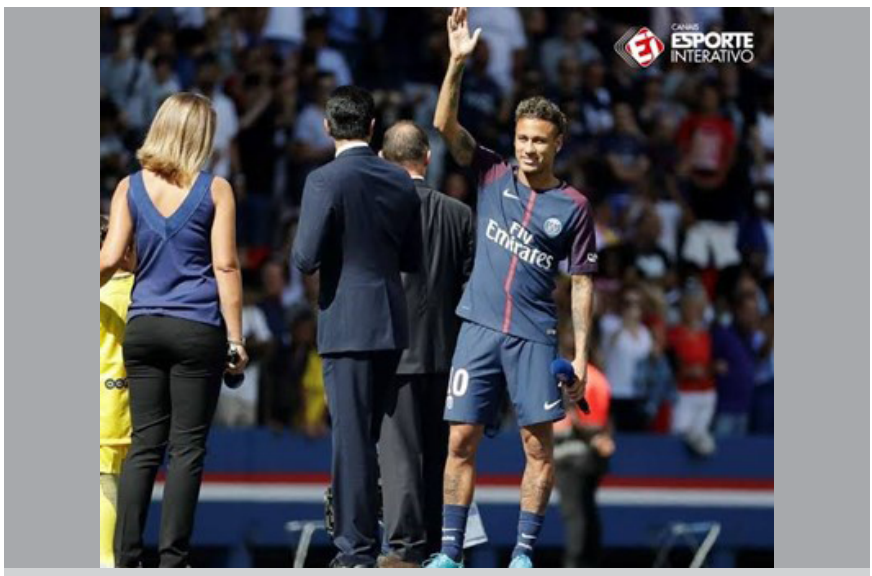

Figure 3. Neymar Júnior's debut in PSG.

Source: Official Twitter account of Esporte Interativo. ${ }^{32}$

\section{Soccer studies}

The etiology of tortuous bones in soccer players seems to be related to tension in the growth phase..$^{11,33}$ The growth plates above and below the knee generate most of the growth in leg length and, for geometric reasons, exert the greatest effect on the axis of the legs. The medial tibial growth plate seems to be particularly more vulnerable than the femoral one. Especially in the prepubertal phase of rapid growth, biomechanical overload in the medial proximal physis of the tibia ${ }^{34}$ due to trauma or chronic imbalance can lead to asymmetric growth. ${ }^{33}$ Cook et al. ${ }^{34}$, who proved that the restricted (and, therefore, asymmetrical) growth of the physis due to an excessive compressive load leads to a progressive varum deformity in the knee. Then, an even greater load concentrates in the medial compartment of the knee, as a vicious cycle. ${ }^{34}$

There is also tension of the hamstrings overlapping both growth plates in the knee region, twice as strong in the medial part of the joint as in the lateral part, causing asymmetrical overload in the joints. ${ }^{33}$ The main sporting gestures performed in soccer (professional and junior leagues) are: running, walking, passing, running with changes of direction, disarming (tackling) and kicking. It is not yet known which specific sports gestures can lead to such excessive compressive asymmetrical load of the knee and determine a varum angulation in growing adolescents ${ }^{35}$.

It is hypothesized that during dribbling and throwing movements, the adductor muscles of the thigh suffer stress ${ }^{33}$ that creates an imbalance between the adductor/abductor muscles. The muscles are then fixed in the medial part of the leg, which increases lateral bone flexion during development, thus generating genu varum. ${ }^{33}$ Frequent and repeated contractions on the sartorius, gracilis, semitendinosus and semimembranosus muscles during sport can also contribute to mechanical overload of the medial physis of the proximal tibia. ${ }^{35}$

Besier et al. ${ }^{36}$ demonstrated that varum and valgum stress is significantly higher in sprints with change of direction than in a normal sprint. These authors also studied valgum / varum stress in football movements and observed that valgum / varum stress is twice as high in unforeseen situations than in previously planned ones.

Changes in direction cause increased mechanical tension, and as neuromuscular fatigue occurs, dynamic knee stabilization is impaired, and the injury rate increases. ${ }^{33 .}$ One of the main determining factors of distribution from medial to lateral load on the knee occurs during almost the entire support phase of normal gait, in which there is a tendency to abduct the knee. Load sports involving intensive running cause a sharp increase in such moments of knee abduction. According to the Hueter-Volkmann Law ${ }^{9,10}$ and Frost's chondral modeling theory, ${ }^{11}$ these sharply increased moments of knee abduction during load sports can interrupt the growth of the medial physis of the proximal tibia due to excessive compressive force on the growth plate. This may be a possible explanation for the relationship between load sports and the emergence of varum on the knees of adolescents. ${ }^{35}$ In addition, soccer cleats restrict players' external rotation in orthostatic position in the support phase, which stimulates bowing of the legs by increasing the varum load on the knee joint. ${ }^{33}$

It is believed that playing soccer competitively also causes knee varusing, proposing that this occurs as a result of microtraumas of repetition imposed on the internal femoral condyles by exhaustive training. ${ }^{37}$ Thaller et al. ${ }^{33}$ found in their study that a considerable percentage of athletes have genu varum (55\% -63\%), which allowed them to conclude that the risk of developing genu varum is higher in adolescents who spend much time playing soccer. ${ }^{33}$

This assertion had been previously confirmed via statistics in studies by Witvrouw et.al., ${ }^{38}$ who assessed 336 young Belgian first division 
soccer players, compared to the control group with 458 young athletes from other sports, and concluded that soccer players develop genu varum more often than the population that does not play soccer. Furthermore, the same study found that soccer players presented genu valgum up to the age group of 12 to 13 years. From the age group of 14 to 15 years, soccer players began to present genu varum. ${ }^{11}$ Both boys who palyed soccer and boys who did not play soccer, from the age of 16 , had genu varum. This finding is in agreement with other studies suggesting an evolution in varum in boys past the end of peak growth. ${ }^{35,38,39}$

Thijs et. al. ${ }^{35}$ conducted a study comparing 265 healthy Caucasian boys, aged 7 to 18 years, who played competitive sports (athletics, field hockey, basketball, volleyball, tennis, badminton and squash) with another 256 boys with the same biological / age characteristics who had never practiced any sports in their lives, with the exception of sports that they palyed in school for 1 hour. Verifying the occurrence of genu varum / valgum by measuring intercondylar and intermalleolar distances (Cl-IM) and with statistical treatment of the data, the author ${ }^{35}$ concluded that practicing load sports (not only soccer) is significantly related to increased occurrence of genu varum in adolescents. Boys who did not play sports presented a negative $\mathrm{Cl}$-IM measure (genu valgum) up to the age group of 13-15 years. In the age group of 16-18 years, the $\mathrm{Cl}-\mathrm{Ml}$ distance became slightly positive. ${ }^{35}$ Boys who played sports showed a negative $\mathrm{Cl}$-IM distance until the ages 10-12 years and became positive (genu varum) from 13-15 years onwards, with an increasing evolution in the age group $16-18$ years. ${ }^{35}$

Colyn et al. ${ }^{40}$ argued that most studies on genu varum and its relationship with sport used only boys as the object of study and defined the alignment of the knee through the difference between intercondylar and intermalleolar distance (Cl-IM). However, the gold standard for this evaluation is a complete leg X-ray (panoramic of lower limbs) since it allows a detailed analysis of the femoral and tibial anatomical parameters and an individual analysis of the right leg and the left leg - a situation that the $\mathrm{Cl}-\mathrm{IM}$ distance does not allow. ${ }^{40}$ Using both measurement techniques, the authors ${ }^{40}$ conducted a retrospective and prospective study with 100 women and 100 men aged 20 to 27 years (all Caucasians), inquiring them about their sports activities while growing up through three age groups and classifying these activities as low and high level according to the Tegner scale. ${ }^{41}$ Standardized full-leg radiographs with weight support were obtained according to Paley and Herzsenberg ${ }^{42}$ with the subjects barefoot and the knees fully extended and the patellas facing forward. The $x$-ray was centered on the knee at a distance of $305 \mathrm{~cm} .{ }^{40}$ The hip-knee-ankle angle was expressed as a deviation of $180^{\circ}$ with a negative value for varum alignment and a positive value for valgum alignment. ${ }^{40}$

Study ${ }^{40}$ concluded that: taking part in high activity sports in adolescence is associated with varum alignment at the end of growth in men, but not in women; more pronounced leg bowing was found in soccer players mainly by a significant association with a lower proximal tibial angle; the study did not find differences between the dominant leg (which does the kicking) and the supporting leg of soccer players, therefore the kicking movement does not seem to be decisive in the development of genu varum; No significant differences were found between the goalkeeper, defender, midfielder and forward positions.

Abreu, Barbosa and Coelho ${ }^{37}$ cite in their study that a large number of soccer coaches prefer adolescent candidates for competitive sport who have varum alignment of the lower limbs as they believe these young palyers to be more skilled.

Chantraine ${ }^{43}$ showed in his study that up to $73 \%$ of retired football players had genu varum.

Regarding complications, professional athletes have an important risk of developing osteoarthritis and this risk is even greater if the athlete has had previous knee injury. There is a strong relationship between the occurrence of genu varum and the significant risk of an athlete developing deterioration of articular cartilage in the medial tibiofemoral compartment of the knee, tibiofemoral osteoarthritis, increased chance of injuries to the patellofemoral joint and patellofemoral pain syndrome. ${ }^{33,38}$

\section{Treatment of axial deviations in athletes}

Surgical treatment in athletes is not the norm since angular deviations of the lower limbs do not interfere with sports practice and are usually asymptomatic. When there is pain, it is usual to opt for special training measures to improve dynamic stability of the knee, along with modified footwear and adjusted intensity of training for the most vulnerable age group. ${ }^{3}$

In cases where the orthopedic doctor, at his clinical discretion, recommends surgical treatment (usually former athletes with chronic pain), an osteotomy is performed.

Osteotomy of the lower limbs is intended to correct the mechanical axis of the long bones to redistribute the forces in the joint by transferring the load to better preserved areas; to correct deformities or to change the patellofemoral joint mechanics. In an individual with arthrosis (for example, a former soccer player), the main objective of osteotomy is chronic pain relief and functional improvement. ${ }^{14,44}$

In varus knee, the procedure of choice is the proximal valgusing osteotomy of the tibia, where the load is shifted to the lateral compartment and the axial forces in the medial compartment of the knee are reduced - in osteotomies for arthrosis, while in osteotomies associated with treatment of cartilage lesions, the normal procedure is to shift the mechanical axis to the center of the knee. In valgus knee, the procedure performed is the varusing osteotomy of the distal femur, which reduces the load in the lateral compartment and rarely aims for hyper-correction of the mechanical axis. The objective in almost all cases is correction toward the center of the knee. ${ }^{14,44}$ Corrections can be performed in the axial, sagittal and /or coronal planes. ${ }^{14}$

\section{CONCLUSIONS}

Other studies need to be conducted to clarify the real etiologies and pathophysiological processes related to genu varum and valgum. The core of such research should be based on the association between soccer practice and development of deformities.

AUTHORS' CONTRIBUTION: Each author contributed individually and significantly to the development of this article. FLC: conception of the article, design of the article, bibliographic research, analysis or interpretation of data for the artcle, drafting, revising content and adequacy, approval of manuscript final version for publication; ELS: bibliographic research, analysis or interpretation of data for the article, drafting, revising content and adequacy, approval of manuscript final version for publication; MVMS: designing the article, providing reference sources and databases for research, drafting, revising content and adequacy, searching a journal for submission, and approval of manuscript final version for publication; MHFL: designing the article, providing reference sources and databases for research, drafting, revising content and adequacy, searching a journal for submission, and approval of manuscript final version for publication; JAG: designing the article, providing reference sources and databases for research, drafting, revising content and adequacy, searching a journal for submission, and approval of manuscript final version for publication; RHY: designing the article, providing reference sources and databases for research, drafting, revising content and adequacy, searching a journal for submission, and approval of manuscript final version for publication. 


\section{REFERENCES}

1. International Federation of Association Football. FIFA Big Count 2006: 270 million people active in football [Internet]. Zürich; 2007 [accessed on 2019 Aug 15]. Available from: https://www.fifa.com/mm/document/fifafacts/bcoffsurv/bigcount. statspackage_7024.pdf

2. Moore K, Dalley A, Agur A. Anatomia Orientada Para A Clínica. 8th ed. Rio de Janeiro: Guanabara Koogan; 2018.

3. Rosenfeld SB. Approach to the child with bow-legs. UpToDate [Internet]. 2019 Sep 17 [accessed on 2019 Oct 10]. Available from: https:/www.uptodate.com/contents/ approach-to-the-child-with-bow-legs?search=geno\%20varo\&source=search result\&selectedTitle $=1 \sim 33 \&$ usage_type $=$ default\&display_rank $=1$

4. Rosenfeld SB. Approach to the child with knock-knees. UpToDate [Internet]. 2019 April 22 [accessed on 2019 Oct 20]. Available from: https://www.uptodate. com/contents/approach-to-the-child-with-knock-knees?search=geno\%20 varo\&source=search_result \&selectedTitle $=9 \sim 33 \&$ usage type=default\&display_rank $=9$

5. Thompson J. Netter Atlas De Anatomia Ortopédica. 2nd ed. Rio de Janeiro: GEN Guanabara Koogan; 2011.

6. Salenius $P$, Vankka $E$. The development of the tibiofemoral angle in children. $J$ Bone Joint Surg. 1975;57(2):259-61.

7. Baruah R, Kumar S, Harikrishnan S. Developmental pattern of tibiofemoral angle in healthy north-east Indian children. J Child Orthop. 2017;11(5):339-47.

8. Heath $\mathrm{C}$, Staheli L. Normal limits of knee angle in white children: genu varum and genu valgum. J Pediatr Orthop. 1993;13:259-62.

9. Hueter C. Anatomische Studien an den Extremitätengelenken Neugeborener und Erwachsener. Virchows Arch Pathol Anat Physiol Klin Med. 1862;25(5-6):572-99.

10. Volkmann R. Impairments of the musculoskeletal system. In: von Pitha F, Billroth T, editors. Handbook For Common And Special Surgery. Stuttgart: Ferdinand Enkle; 1869. p. 845-920.

11. Frost H. A chondral modeling theory. Calcif Tissue Int. 1979;28(1):181-200.

12. Shultz SJ, Houglum PA, Perrin DH. Assessment Of Athletic Injuries. Champaign: Human Kinetics; 2000.

13. Barros Filho T, Lech O. Exame Físico Em Ortopedia. 3rd ed. São Paulo: Sarvier; 2017.

14. Motta G, Barros T. Ortopedia E Traumatologia. Rio de Janeiro: GEN Guanabara Koogan; 2017.

15. Castro R. Estrela Solitária: Um Brasileiro Chamado Garrincha. São Paulo: Companhia das Letras; 1995.

16. Garrincha, a "alegria do povo", morreu há 20 anos. UOL News [Internet]. 17 jan 2003 [acesso em 3 jul 2019]. Disponível em: https://noticias.uol.com.br/ lusa/ultnot/2003/01/17/ult611u18343.jhtm

17. 20-01-1983: Morre Mané Garrincha, ídolo do futebol brasileiro. Radio Jota FM [Internet]. 20 jan 2017 [acesso em 1 jul 2019]. Disponível em: http://www.radiojotafm.com. br/noticias/20-01-1983-morre-mane-garrincha-idolo-do-futebol-brasileiro/1111/.

18. Jogadores Com a Perna Torta. Culturamix.com [Internet]. 2019 [acesso em 15 jul 2019]. Disponível em: https://famosos.culturamix.com/esportistas/ jogadores-com-a-perna-torta

19. Landi B. "Anjo das pernas tortas", Garrincha completaria 80 anos nesta sexta-feira. Terra [Internet]. 18 out 2013 [acesso em 4 nov 2019]. Disponível em: https://www. terra.com.br/esportes/botafogo/anjo-das-pernas-tortas-garrincha-completaria-80-anos-nesta-sexta-feira,a39d29a27f8c1410VgnCLD2000000ec6eb0aRCRD.html

20. Botafogo de Futebol e Regatas. Garrincha ficou conhecido como o Anjo das Pernas Tortas! E driblava quem aparecesse na sua frente! \#GarrinchaEterno \#OMaiorDeTodos. Twitter [Internet]. 18 out 2016 [acesso em 18 dez 2019]. Disponível em: https://twitter.com/botafogo/status/788380320483700736

21. Mané Garrincha, o "anjo das pernas tortas". Estadão [Internet]. 21 jan 2013 [acesso em 30 ago 2019]; Esportes. Disponível em: https://esportes.estadao. com.br/galerias/geral, Mane-garrincha-O-Anjo-das-pernas-tortas,7285

22. Dória P. O que há com Leandro: mal de cowboy. Placar [Internet]. 10 maio 1985 [acesso em 15 jan 2020]. Disponível em: https://books.google.com.br/books?id=XxgmmgK4EOYC\&pg=PA22\&lpg=PA22\&dq=le andro+sele\%C3\%A7\%C3\%A3o+brasileira+perna+torta\&source=bl\&ot $\mathrm{s}=\mathrm{C} 8 \mathrm{~b} 8 \mathrm{FnZybp} \& \mathrm{sig}=\mathrm{ACfU} 3 \mathrm{U} 13 \mathrm{ex} 8 \mathrm{tT}$ sul-IpVtMns1050oDaL2w\&hl=ptBR\&sa $=X \& v e d=2 a h U K E w i 719 m H x N P n A h X R I L k G H V I h C i U q 6 a e w c 3 o e c a o q$ aq\# $\mathrm{v}=$ onepage $\& \mathrm{q}=$ leandro\%20sele\%C3\%A7\%C3\%A30\%20brasileira\%20 perna\%20torta\&f=false
23. Gueiros PM. Fla, 30 anos do Mundial de 1981: anjo rubro-negro de pernas tortas. O Globo [Internet]. 10 dez 2011 [acesso em 10 dez 2019]. Disponível em: https://webcache.googleusercontent.com/search?q=cache:IXrEeXBctnEJ: https://oglobo.globo.com/esportes/fla-30-anos-do-mundial-de-1981-anjo-rubro-negro-de-pernas-tortas-3425659+\&cd=11\&hl=pt-BR\&ct=clnk\&gl=br

24. Donke A, Daga B, Valente R, Bianchini V, Zanei R. Romário, 50 anos: 'Quando nasci, papai do céu apontou para mim e disse: Esse é o cara'. ESPN Brasil [Internet]. 29 jan 2016 [acesso em 15 jul 2019]. Disponível em: http://www.espn. com.br/noticia/571807_romario-50-anos-quando-nasci-papai-do-ceu-apontou-para-mim-e-disse-esse-e-o-cara

25. Romário passa por cirurgias no joelho e terá alta quinta-feira. UOL [Internet]. 16 set 2008 [acesso em 3 jul 2019];Esporte. Disponível em: https://www.uol. com.br/esporte/futebol/ultimas/2008/09/16/ult59u171094.jhtm

26. Romário se recupera das cirurgias da perna esquerda. EGO [Internet]. 29 set 2008 [acesso em 4 jul 2019]. Disponível em: http://ego.globo.com/Gente/ Noticias/0,,MUL778238-9798,00-ROMARIO+SE+RECUPERA+DAS+CIRURGI AS+DA+PERNA+ESQUERDA.html.

27. Dunga deverá deixar hospital em Porto Alegre neste domingo. Clicrbs.com.br [Internet]. 5 abr 2008 [acesso em 9 jul 2019]. Disponível em: http://www.clicrbs. com.br/especial/sc/qualidade-de-vida-sc/19,0,1818394.

28. Ogliari E. Técnico Dunga se submete a duas cirurgias em Porto Alegre. Estadão [Internet]. 5 abr 2008 [acesso em 10 jul 2019];Esportes. Disponível em: https://esportes.estadao.com.br/noticias/ futebol,tecnico-dunga-se-submete-a-duas-cirurgias-em-porto-alegre, 151754

29. Silva T. Rivaldo: Que fim levou? Terceiro Tempo [Internet]. 2013 [acesso em 11 jul 2019]. Disponível em: https://terceirotempo.uol.com.br/que-fim-levou/rivaldo-4468

30. Rivaldo passa por cirurgia no joelho aos 43 anos e diz estar "assustado." Globo Esporte [Internet]. 16 set 2015 [citado em 8 jul 2019]. Disponível em: http://globoesporte.globo.com/sp/campinas-e-regiao/futebol/noticia/2015/09/ rivaldo-passa-por-cirurgia-no-joelho-aos-43-anos-e-diz-estar-assustado.html

31. Santos G, Musetti L. "Joelhos de Neymar" e trabalho extra: a luta de Cleber por espaço no Santos. Globo Esporte [Internet]. 27 maio 2017 [acesso em 5 jul 2019]; Santos. Disponível em: https://globoesporte.globo.com/sp/santos-e-regiao/futebol/times/santos/noticia/joelhos-de-neymar-e-trabalho-extra-a-luta-de-cleber-por-espaco-no-santos.ghtml

32. Esporte Interativo. CHEGUEl! Cheguei chegando, bagunçando a zorra toda. Twitter [Internet]. 5 ago 2017 [acesso em 8 nov 2019]. Disponível em: https:// twitter.com/esp_interativo/status/893845404982403072

33. Thaller P, Fürmetz J, Chen F, Degen N, Manz K, Wolf F. Bowlegs and intensive football training in children and adolescents. Dtsch Arztebl Int. 2018;115(24):401-8.

34. Cook S, Lavernia C, Burke S, Skinner H, Haddad R. A Biomechanical Analysis of the Etiology of Tibia Vara. J Pediatr Orthop. 1983;3(4):449-54.

35. Thijs Y, Bellemans J, Rombaut L, Witvrouw E. Is High-Impact Sports Participation Associated with Bowlegs in Adolescent Boys? Med Sci Sports Exerc. 2012;44(6):993-8.

36. Besier T, Lloyd D, Cochrane J, Ackland T. External loading of the knee joint during running and cutting maneuvers. Med Sci Sports Exerc. 2001;33(7):1168-75.

37. Abreu AV, Barbosa JRP, Coelho FJP. Alinhamento dos joelhos no plano frontal dos 12 aos 17 anos. Rev Bras Ortop. 1996;31(1):83-8.

38. Witvrouw E, Danneels L, Thijs Y, Cambier D, Bellemans J. Does soccer participation lead to genu varum? Knee Surg Sports Traumatol Arthrosc. 2009;17(4):422-7.

39. Cahuzac J, Vardon D, Sales de Gauzy J. Development of the clinical tibiofemoral angle in normal adolescents. A study of 427 normal subjects from 10 to 16 years of age. J Bone Joint Surg Br. 1995;77-B(5):729-32.

40. Colyn W, Agricola R, Arnout N, Verhaar J, Bellemans J. How does lower leg alignment differ between soccer players, other athletes, and non-athletic controls? Knee Surg Sports Traumatol Arthrosc. 2016;24(11):3619-26.

41. Tegner Y, Lysholm J. Rating Systems in the Evaluation of Knee Ligament Injuries. Clin Orthop Relat Res. 1985;(198):42-9.

42. Paley D, Herzenberg J. Principles of Deformity Correction. Berlin: Springer Berlin; 2014.

43. Chantraine A. Knee joint in soccer players: osteoarthritis and axis deviation. Med Sci Sports Exerc. 1985;17(4):434-9.

44. Canale S, Beaty J. Campbell Cirurgia Ortopédica. 12th ed. Rio de Janeiro: GEN Guanabara Koogan; 2017. 